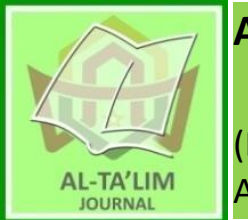

AL-TA'LIM JOURNAL, 26 (1), 2019, (65-75)

(Print ISSN 1410-7546 Online ISSN 2355-7893)

Available online at http://journal.tarbiyahiainib.ac.id/index.php/attalim

\title{
Implementation of Integrated Learning Based Integrated Islamic School Network Curriculum in SMA ABBS Surakarta
}

\author{
Received: 30 $0^{\text {th }}$ January 2019; Revised: $04^{\text {th }}$ February 2019; Accepted: $28^{\text {th }}$ February 2019 \\ Permalink/DOI: http://dx.doi.org/10.15548/jt.v26i1.507
}

\section{Muhammad Munadi *) \\ Institut Agama Islam Negeri Surakarta, Indonesia. \\ E-mail: munadimahdiputra@gmail.com}

\section{Fitri Ana Ika Dewi}

Institut Agama Islam Negeri Surakarta, Indonesia.

E-mail: fitriana.kade@gmail.com

\section{*) Corresponding Author}

\begin{abstract}
This research aims to identify the implementation of integrated learning method based on Integrated Islamic School Network curriculum in SMA ABBS of Surakarta. This research is aimed to analyze the integrated phases used in SMA ABBS. Descriptive qualitative research was applied where the data taken from document, events, and informants. The results of the research show that there are three phases of integrated learning: material comprehension, integrated understanding, and practicing the integrated learning. The implementation of integrated learning method in SMA ABBS develops intellectual intelligence (IQ), emotional intelligence (EQ), and spiritual intelligence (SQ). The implementation of integrated learning method based on Integrated Islamic School Network curriculum has ideological foundation sourced from the holy Qur'an and As-Hadits. The successful implementation of this method is due to good cooperation between the committees involved.
\end{abstract}

Keywords: Integrated Learning; Integrated Islamic School Network; Intellectual-emotional spiritual intelligence

How to cite: Munadi, M., \& Dewi, F. (2019). Implementation of Integrated Learning Based Integrated Islamic School Network Curriculum in SMA ABBS Surakarta. Al-Ta Lim Journal, 26(1). doi:http://dx.doi.org/10.15548/jt.v26i1.507

\section{INTRODUCTION}

Curriculum in Indonesia has undergone some reforms to develop the quality of education. The curriculum improvement should consider to the components involved. School committee does not stand alone to develop education (Hopkins \& Reynolds, 2001; Ingram, 2014). School committee should work together with others. Since, the success of its implementation lies on the cooperation between the committees involved either directly or indirectly in learning process, among others: teachers, students, principals, staff, parents, school policy, and government (Hill, 2007; Tam, 2014; Van den Akker, 2004).
Curriculum reflects the identity of educational institution. Some institutions offer their features through the curriculum. The implementation of a curriculum must be synergized with the vision, mission, and goals (Boud \& Solomon, 2000; Hatton, 2012; Karseth, 2004; Moore, 2001, 2003). In accordance with this, Banks (2015) says that vision is designed in line with mission to achieve the goals of learning process. Integrated Islamic School Network as a new curriculum model has a different curriculum standards with others. Integrated Islamic School Network is adopted from curriculum of the Ministry of Education and Culture. It combines between national curriculum and Islamic Boarding curriculum by giving extra religious lessons (Amin, Yusof, \& Haneef, 
2012; Hashim, 2007; Lubis, 2015; Lubis \& Wekke, 2009; Osman, 2013).

Integrated Islamic School Network refers to the holy Quran and Al Hadits as its basis. Knowledge is classified into two kinds according to the source, namely: Perennial Science and Acquired Science. Perennial Science is received from God's revelation though Al Quran and hadits, while Acquired Science is obtained through series of experiences (Hasan, 2009, 2012). Furthermore, Hasan (2012); Salleh (2009) argued that integrating these two kinds of knowledge into a curriculum leads us to develop a teaching methodology. The teaching methodology is not only limited to teaching practice, but it is also related to the issues within the educational field, such as: management, administration, teacher, staff, textbooks, and other learning sources. The integrative mindset leads to combine between the education of religion and science.

Basically, Islamic education has a special characteristic which is referred to $\mathrm{Al}$ Quran and $A l$ Hadits. Integrated Islamic School Network is not only realized on educational design, but it should also be implemented in the operational education systems (Lukens-Bull, 2001; Pohl, 2009; Tan, 2012; Zuhdi, 2006). There are several schools in Surakarta which implies Integrated Islamic School Network. One of them is Senior High School Al Abidin Bilingual Boarding School (SMA ABBS) of Surakarta. SMA ABBS was established in 2012 and started the academic year in 2012/2013. SMA ABBS belongs to a new school, but it has scored achievements in various fields of science both academics and non-academics. The achievement cannot be separated from the role of the committees involved directly and indirectly to the learning process. Further, a learning method becomes another supporting factor which directly connects to the learning process. The learning method used by SMA ABBS which is most related to the concept of Integrated Islamic School Network curriculum is integrated learning method. It facilitates students in understanding the material and motivates them to be more active in learning process. Drake (2007); Parsons (2004) he explains that in the integrated curriculum, the planned learning experiences not only provide the learners with a unified view of commonly held knowledge (by learning the models, systems, and structures of the culture) but also motivate and develop learners' power to perceive new relationships and thus to create new models, systems, and structures (Brewer, 2002).

The integration of one lesson and others makes students easy to practice the theory in their everyday life. Integrated learning method integrates learning activities into all aspects of students' development, such as: cognitive, social-emotional, language, morality, religious values, physical motor, and art (Koskinen, 2003; Pahl-Wostl \& Hare, 2004; Sylvén, 2004). Those aspects are correlated into the learning activity and integrated by a theme. In addition, integrating those aspects trains students to develop their potencies maximally, such as: exercising motor skills, observing, counting, reminding, comparing, classifying, role playing, and exploring ideas (Hardini \& Puspitasari, 2012; Kurniawan, 2014; Wati, 2010). Basically, integrated learning method is done by correlating one lesson and others through a theme. Murfiah (2017) explained that in an integrated methodology interdisciplinary topics are arranged around overlapping concepts and emergent patterns. This process blends the disciplines by finding overlapping skills, concepts, and attitudes found across the disciplines. This methodology is a result of shifting related ideas out of the subject matter content. Further, he emphasized that an important process of the integrated methodology is that teachers work together on the topics or themes as commonalities emerge. The concept is described as the picture below:

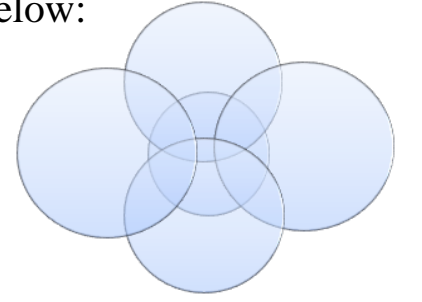

Picture 1: integrated method by Fogarty 
Picture 1 shows us an integrated method by Fogarty which applies on a concept that a subject is correlated to others by a type of themes. In accordance to this, Ghosh \& Pandya (2008) states that an integrated study is one in which children broadly explore knowledge in various subjects related to certain aspects of their environment. He correlates the subjects among the humanities, communication arts, natural sciences, mathematics, social studies, music, and art. These subject are connected each others. Implementation of integrated learning method is based on the theme that has been determined by the teacher (Carbonell, Knoblock, \& Minton, 2014; De Graaf \& Kolmos, 2003). Teacher organizes the teaching and learning activity to make it more structured. Theme functions as a reference of the material based on the subject, discussion unit, and students need. Therefore, teacher decided the theme considering to the subject, discussion unit, and activities based on the theme.

Considering to the Integrated Islamic School Network curriculum, the implementation of integrated learning in SMA ABBS is referred to Al Quran and $A l$ Hadits. As Khuzaemah said that learning process must bring students to the religious consciousness. It encourages them to inspire for true life through the spiritual values, motivation, wisdom stories, prophet's stories, and history of Islamic figures (Khuzaemah, 2016). In implementing the method, teachers should integrate their lesson with the Islamic values, such as: God's gift, God's greatness and others.

\section{METHOD}

This descriptive qualitative research aims at describing the integrated design of Religion, Social, and Science based on Integrated Islamic School curriculum. The data sources are documents, events, and informants. The documents are profile book of SMA ABBS that includes the data of vision, mission, curriculum, learning methods, and school programs. Events are class observation and Forum Group Discussion (FGD). Meanwhile, the informants are an interview to the principle and Vice Principle of Curriculum SMA ABBS. The research uses sampling technique for the class observation. They are history, physics, and religion classes.

\section{RESULT AND DISCUSSION}

Implementation of integrated learning in SMA ABBS Surakarta is done through integration between lesson and Islamic values referred from Al Quran or Al Hadits. The integration is done to all lessons. The classification of lessons in SMA ABBS is divided into four categories based on Ministry of Education and Culture regulations, they are: group A (General A), group B (General $\mathrm{B})$, group C1 (Science Interest), and group C2 (Language Interest). General A includes religious and akhlaq, tahfidz quran, Pancasila and Civic Education, Indonesian language, math, Indonesian history, English language, and conversation. General B includes culture and art, sport, entrepreneurship, and Javanese language. The lessons in General $\mathrm{A}$ and General B are obligatory lessons for all students of SMA ABBS.

Science interest is a set of lessons for students who interest to science. Science interest includes math, physics, chemistry, and biology. Language interest is a choice for students who have tendency to language. It focuses to deepen foreign language competence. Language interest includes English and Arabic language. The integration between them is tied up by a theme that can be illustrated as below:

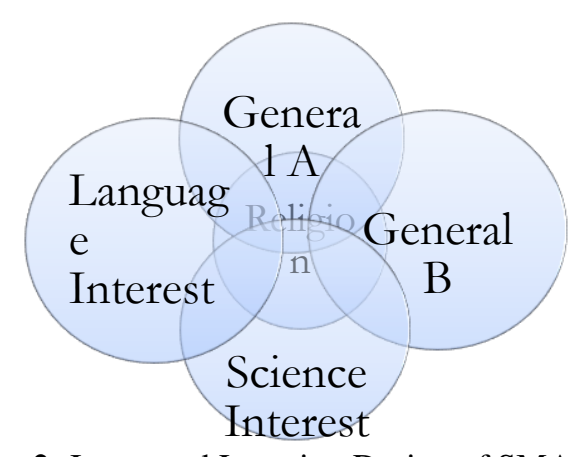

Picture 2: Integrated Learning Design of SMA ABBS 
Picture 2 shows us an integrated design which correlates each group of lessons with the religion. In principle, through a theme of certain topic, teacher correlates religion with all subjects of each group. Teacher correlates General A which includes of Pancasila and Civic Education, Indonesian language, math, Indonesian history, English language, and conversation with religion. Teacher also integrates General A and B and gives Islamic moral values referred from $\mathrm{Al}$ Qur'an or Al Hadist in accordance to the topic. For religious and akhlaq, tahfidz quran, teacher correlates them with the conditions occurring in daily life both social and natural phenomena that happen around us.

Integrated learning in group B is done by the correlation between culture and art, sport, entrepreneurship, and Javanese language with religious values. Besides that, trough a theme, teacher also integrates the subjects in group $\mathrm{C} 1$ with the subjects of General B and C2. For language interest also has high correlation to General A. Teacher integrates a certain theme of foreign language skill with social and akhlaq. The last, the subjects in science interest are correlated to religion, language interest, and group $\mathrm{A}$. Basically, the main point of the integration is that students practice those lessons based on Islamic guidance.

In implementing the integrated learning in SMA ABBS, there are some phases that should be done by teacher. The phases are describes on the picture below:

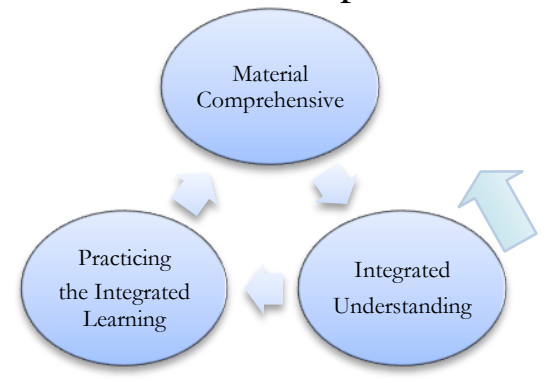

Picture 3: Integrated Learning Phases of SMA ABBS

Picture 3 shows us integrated learning phases of SMA ABBS which are correlated one and others. Material comprehensive is a learning activity to explain the material lesson. The activity is focused to discuss the topic. Further, integrated understanding phase is a phase when teacher integrates between material and religious values. It is a learning activity process to deepen students' understanding by correlating the topic lesson with Islamic values referred to Al Quran and Al Hadits. Practicing the integrated learning is the result from integrated learning process. The results of learning process can be different between one lesson and others. These depend on the type of the lesson.

In implementing the phases, the material comprehensive phase is not always done for the first phase. The material comprehensive phase and integrated understanding phase can be turned one another based on the need and the strategy used in learning process. Therefore, teacher can apply leaning process by the arrangement of: (a), (b), and (c) or (b), (a), and (c). The rule is: (a) for material comprehensive, (b) for integrated understanding, and (c) for practicing the integrated learning. The three phases cannot be separated each other, because they integrate and complete one and others.

\section{Material Comprehensive}

To begin a lesson, teacher greets students by saying 'assalaamu'alaikum warohmatullohi wabarokaatuh', asks them to pray and to read the holy Qur'an together. Some teachers ask students to read several verses continuing from $J u z, 1$ forth. However, others ask them to read the verses by their meaning in accordance to a topic. The meaning of the verses gives students a guidance to predict some points of the material comprehensive. In this step, teacher does not discuss clearly about the verse yet. It is aimed to prevent an overlapping from one step to others.

The introductory activity above illustrates integrated learning. Teacher's greeting is a small action that has a great positive impact to students. Students are habituated to pray for one and others. Beside, reading the Holy Qur'an brings students close 
to Allah. However, teacher limits discussion about the verse to focus on the material. For example:

Teacher asked students to read the Holy Qur'an (Yaasin 37-40). Having read the verses, teacher asked them to read the meanings that explain about rotation. Further, the teacher explain, discuss, do question and answer about the rotation.

The result of the observation in physic class illustrates that there is an integrated learning between the verses and topic. Teacher touches on the meaning of the verses and correlates them to the material lesson. In this step, teacher only conveys that the verses relate closely to the topic and does not explain deepy about the integrated between the verses and the rotation. It is aimed to avoid an overlapping discussion between material comprehensive step and integrated understanding between material and religious value step. However, this identification becomes a material outline for students to predict about the topic. After reading Yaasin 37-40 and the meaning, teacher focuses on material discussion about rotation.

\section{Integrated understanding between material and religious value}

Teacher refers to Al Quran and $\mathrm{Al}$ Hadits to show a correlation between the topic and religion. Teacher integrates both of them by inserting Islamic values into the material lessons. It is prevailed in all subjects that are encompassed on: religion, history, language, social, science, art and culture, and sport. Basically, the knowledge of these classification subjects are written and explained in Al Quran.

In history subjects, teacher correlates the topics to wisdom stories of prophets, Khulafa Urashiddin and patriots or Islamic values that correlate to the topics. For example, topic on prince Diponegoro, teacher teaches the struggle of prince Diponegoro. Without overriding about the time and the place of his died, teacher emphasizes about his struggle. How prince Diponegoro could arouse the jihad spirit through his struggle and why prince Diponegoro did the war are the main points to be discussed. Teacher relates it to the willing of jihad in Islam. Teacher correlates the struggle of Prophet Muhammad SAW.

The correlation between theme of prince Diponegoro and the story about Prophet Muhammad SAW shows us an integrated leaning method. Students can take lessons about the spirit of struggle, sacrifice and leadership from the history lesson. Integrating between material lessons with religion makes students understand more about the topics. It closely relate to their understanding competence. By theorems, figures or wisdom stories related to the topic make students imagine the figures, sense the stories, or understand the interpretation of the theorems.

The implementation of integrated learning in language subjects closely relate to the culture where the language is used. Language subjects include Indonesian, Javanese, English, and Arabic. In teaching English language, teacher confronts with a culture problem, it is described as below:

I ever displayed English dialog on a movie trailer. It showed us natives speakers that did not wear veil; they wore short T-shirt that disclosed their aurat. If I gave them non-native, they could not learn about the pronunciation well. For me, to find the proper one -natives who close their aurat- is difficult. It is a problem when I have to integrate with the Integrated Islamic School Network curriculum in finding the material of English subject.

The explanatory description from English teacher on Forum Group Discussion above implies a difficulty which correlates to culture problem. Without ignoring the inherent culture, teacher needs to be more careful in choosing the video and gives more 
explanations to avoid misunderstanding in interpreting western culture. One of them is by selecting material lesson. Teacher emphasizes on the aspects of daily life, such as politeness, expressions and others that correlate to communication aspect. Based on the sources of Al Quran and As Hadits, teacher inserts Islamic values on the material of expressions that relate directly to the students' morals and attitudes in daily life.

The example of integrated learning is emphasized on language function itself. Teacher inserts a Hadits about politeness: Ibnu Abbas from Rosululloh saw, he said that "people do not belong to us to whom they do not respect to the older and do not care to the younger, they do not govern to goodness and do not avoid bad thing". [HR Ahmad AtTirmidzi and Ibnu Hibban]. From the politeness theory, teacher correlates with the Hadits. It is a form of integrated leaning in which teacher integrates the topic to the moral values of daily communication. Therefore, this step relates closely to the step of practicing integrated leaning.

In science subjects, implementation of integrated learning is done by referring to $\mathrm{Al}$ Quran and $A l$ Hadits. Science subjects include: physic, chemistry and biology. Teacher of physic integrates topic, for example: rotation with verses on Al Qur'an: Al Imron: 190, Yunus: 6, An Naml: 88, Al Furqon:45, Yaasin: 37-40. First, teacher asks students to read Yaasin: $37-40$ and the meaning in the introductory activity, but teacher does not explain yet about the integration between the verses and the rotation. Teacher only gives points as guidance to the topic. After focusing on explanation and discussion about the rotation, teacher correlates the discussion with the verses of Al Qur'an.

In art and culture lesson, teacher asks students to pray and read the holy Qur'an in the introductory activity. The implementation is also reflected during the learning process. Teacher correlates the topics with theorem related to the discussion. In the end of the leaning process, students pray to Allah.
Teacher also says good bye to greet them by saying 'wassallamu 'alaikum warohmatullohi wa barokatuh', and students answer by 'wa'alaikum salam warohmatullohi wa barokatuh'.

\section{Practicing the Integrated Learning}

Each subject has its type of practicing integrated learning that can be different with others. The different type of practicing integrated learning is influenced by the type of lessons. Lessons which include on attitude and skill development are monitored and evaluated based on students' daily behavior. These lessons include of language, akhlaq and religion, Pancasila and Civic Education, art and culture, entrepreneurship, and sport. Lessons that include on knowledge competence are evaluated through their analysis. These include science and math.

Practicing integrated learning on Indonesian, Javanese, English, and Arabic languages is monitored based on their attitude on using the language in daily life. Teacher cooperates with parties getting in touch with students, such as: teachers, staff, the principle, and parent. Besides that, teacher develops students' language skill on language competitions such as: speech contests that are held by internal, Integrated Islamic School Network or other institutes. Teacher monitors students' competence on integrating language and religion. Students are taught to give Islamic values on their speech.

Practicing integrated learning on pancasila and civic education, akhlaq, and religion is shown from their attitude toward others. In school environment, teacher cooperates with parties getting in touch with students, such as: teachers, staff, and the principle. In home environment, teacher cooperates with parent to monitor students' attitude. Teacher asks parent about students' behavior toward parent, friends, and neighbors.

Integrated learning method based on Integrated Islamic School Network is not only implemented in classroom, but the 
implementation is also done through religious program of SMA ABBS. The religious program includes some religious activities that are held routinely to improve students' faith to Allah SWT. It involves some activities below:

a. Reading the Holy Quran. This activity is practiced by students and teachers every day at $06.50 \mathrm{WIB}$. It is done continually around 8-10 minutes in the morning. The activity makes students love to Allah SWT and avoids them to do bad things.

b. Mentoring Class. Mentoring class emphasizes on developing spiritual and emotional intelligence. It discusses about religion, social concern, and problems in everyday life. This program supplies students to be more mature in solving the problems of life wisely. Teacher motivates students for being a good character.

c. Memorazing Quran (Tahfidhul Quran). Tahfidhul Quran program targets students to memorize Al Quran at least three juzs for three years. For students who interest in Tahfidhul Quran should memorize 10 juzs for three years by a special teaching program. They will get a special class that focuses in special Tahfidhul Quran program.

d. Friday Al Kahfi. It is an activity of reading Q.S Al Kahfi for every Friday morning before the learning process is started. It is aimed at carrying on God's religion.

e. Speech. This activity is done after praying dhuhur. Students do speech in front of teacher and friends. Speech program prepares them as Islamic preachers. Besides that, speech program also tries students' courage for doing a speech in front of public. The routinely program makes them more creative to compile material.

f. Dzikir. Students read dzikir Al Ma'tsurat after praying ashar. Al ma'tsurat includes several prayers and some Qur'an verses. Dzikir program habituates students to remember Allah as always. It can infuse students' love to Allah SWT and can control their attitude. Remembering Allah
SWT makes them ignore for doing bad things that are forbidden to do.

Religious program is not only aimed at developing spiritual intelligence, it also honed emotional and intellectual intelligence. Intellectual intelligence is maximally developed in Tahfidzul Quran activity. Besides to make students closer to Allah SWT, Tahfidzul Quran gives good impact to intellectual intelligence. Accordingly, it takes a high brain work. When students memorize verses of the Holy Quran, they need to repeat them continuously to keep their recitations. The repeating activity triggers students' brain more active. This condition sharpens their memory.

Tahfidzul Quran needs a great concentration. First, students learn how to read the postulates correctly based on the tajwid (the principles of reading the Holy Quran). Second, they memorize the postulates word by word to build a verse. Then, they memorize it to complete as the whole verse. Finally, students have to keep them by repeating the recitations in memory. Those activities activate and develop their brain's cells.

Developing students' intellectual intelligence can also be derived from speech activity. Speech activity does not only trains students' mental, it also stimulate their intelligence. Student needs to make text before performing speech. Compiling a text involves pretty high working system of students' brain, because they have to integrate their theme of discussion with religious knowledge. The text must include Islamic moral values to be delivered to their friends as the listener. In according to it, Perkins advocates that a concern with connecting things up, with integrating ideas, within and across subject matters, and with elements of out-of-school life, inherently is a concern with understanding in a broader and a deeper sense. Accordingly, there is a natural alliance between those making a special effort toward integrative education. 
In working out the emotional intelligence, students need to get used to control their emotion and lust. Reading Quran and Dzikir can increase students' faith and infuse students' love to Allah SWT. Students read God's postulates and repeatedly pronounce God's name. Those activities make them remind to Allah SWT, and make them be grateful for God's gifts. For these reasons, reading Quran and dzikir can control them avoiding some deviant things, because remembering Allah makes students fear to do forbidden things.

Integration between intellectual, spiritual, and emotional intelligence is aimed at bringing up students' love to Allah SWT. When students have good spiritual intelligence, they are easier to pressure their lust and emotion. It will lead them to be positive thinking in solving their problems of life and think rationally facing anything around. Besides that, remembering to Allah SWT as always also controls them from negative globalization impacts.

The implementation of integrated learning method is also reflected from Character Building program. Character Building is one of excellent programs in SMA ABBS to build and educate students' character. Character Building program includes:

a. Self-confidence Saturday for Confidence. It is carried out every Saturday morning. Students do a speech in front of their friends and teachers. For each Saturday, four students perform a speech in different languages. A student may do a speech in English and others are in other languages. The four different languages are: English, Arabic, Indonesian, and Javanese. This program trains students' confidence and develops their language competence. Each student must compile the text based on his or her theme that includes Islamic moral values and motivation for their friends.

b. Love the cleanness Tuesday Cleaning. The program habituates students to keep cleaning of the school environment. It undertakes every Tuesday morning. Each student cleans his or her class together with the member of the class. It brings them up about God's command of cleanness. Furthermore, it also educates them about the togetherness and cooperation.

c. Save Monday saving. Every Monday, students are recommended to save their money. It educates them not to be an improvident person. For this reason, students need to be habituated to save money.

d. Social concerns. Friday for Charity. Every Friday, students are encouraged to give charity to help their friends whom they are in a difficult economic condition. This program infuses students' concern toward others. It makes them more sensitive to others. It is a form of integrated correlation between religion and social. Sharing and giving are kindness that must be acquainted to students from the early age. Social and disaster funds. When a disaster is occurred or a student is afflicted misfortune, members of the school carry out social and disaster funds. It infuses students' sensitive toward others' grief.

e. Discipline. Outbound Camping and Motivation (OCM) program trains students' discipline and independence. Students must prepare everything that they need by themselves. The activity involves others in a team, so the discipline is needed to keep solidarity. For that reason, undisciplined student will harm and hamper others.

f. Entrepreneurship. An entrepreneurship program is carried out in the holiday for students of $2^{\text {nd }}$ class. Students are assigned to make plan, practice, and evaluation about their entrepreneurship product either in a form of goods or services. The program gives a great benefit for students to supply them about entrepreneurship.

g. Leadership. Leadership program is aimed at preparing students as a great Islamic leader who holds tightly to the Islamic laws as always. This program trains 
students' confidence and courage. A leader should be able to control people whom he leads, so self-confidence is the main principle to become a good leader. Besides, courage is also important because a leader should have courage to decide and respond everything quickly and precisely.

Those activities are form of integrated learning implementation. The activities are concrete result of learning material. The practice of Friday for Charity and social and disaster funds programs are the result of integrated learning implementation of religion and social design. As those are illustrated from the implementation of integrated learning in social field through the social concern activities, Allah SWT command us to share and give to people in need.

Economy training requires a special skill that is gotten by some experiences. Indeed, the result will be difference for people who do practice directly and only learn from others' experiences. Moreover, entrepreneurship requires precision, detail, tenacity, and money management. It integrates to the religion about kind of good jobs. Based on the Islamic religion, marketing is one of good jobs. For those reasons, it becomes one of the character building programs in SMA ABBS. Tuesday cleaning and Monday saving are the character building activities that develop emotional intelligence. In both the two activities, students are trained to push their desire. Monday saving controls their desire to spend their money exaggeratedly. They recognize the importance of saving money. Tuesday cleaning habituates students to keep cleanliness as always, and restrain them to pollute the environment. Those activities give positive effect to their lifelong learning. Lake says that integrated curriculum is an educational approach that prepares children for long life learning. There is a strong believe among those who support curriculum integration that schools must look at education as a process for developing abilities by life in the twenty-first century, rather than discrete, departmentalized subject matter.

\section{CONCLUSION AND RECOMMENDATION}

Implementation design concept of integrated learning in SMA ABBS Surakarta based on Integrated Islamic School Network curriculum is done through three phases. These are material comprehension, integrated understanding, and practicing the integrated learning. The three phases cannot be separated each other, because they are correlated one and others. The implementation of integrated learning method based on Integrated Islamic School Network is an effort to develop intellectual, spiritual, and emotional intelligence through some activities of religious program: reading Quran, mentoring, tahfidhul Qur'an, dzikir, Friday Kahfi, and speech. Integrated learning method leads to build students' character through some program: Saturday for Confidence, Tuesday clening, Monday saving, Friday for charity, social and disaster funds, outbound camping and motivation, and entrepreneurship.

The successful implementation of integrated learning method is influenced by the committees involved both directly and indirectly related to the learning process. Some teachers find difficulties to integrate internalize Islamic values to their subject because of inadequate of Islamic references problem. Besides that, inappropriate cultures to Integrated Islamic School Network curriculum become some obstacles to integrate science and religious education. For those researchers who want to analyze more about integrated method can analyze on comparative study among two schools that apply integrated leaning method. Researchers can compare the type of integrated learning used by schools. Are different type or phases influence the result competences. This research explicates the theory and evidences behind the arguments. Therefore, this article is helpful to be reviewed. 


\section{REFERENCES}

Amin, R. M., Yusof, S. A., \& Haneef, M. A. (2012). The Effectiveness of an Integrated Curriculum: The Case of the International Islamic University Malaysia. Proceedings of the $8 \mathrm{Th}$ International Conference on Islamic Economics and Finance.

Banks, J. A. (2015). Cultural diversity and education: Foundations, curriculum, and teaching. Routledge.

Boud, D., \& Solomon, N. (2000). Work as the curriculum: Pedagogical and identity implications. Conference Organized by Research into Adult and Vocational Learning (RAVL) at the University of Technology, Sydney (UTS). Gleebooks," Studies in Continuing Education," and the Faculty of Education at UTS Provided Some Financial, 55. ERIC.

Brewer, T. M. (2002). Integrated curriculum: What benefit? Arts Education Policy Review, 103(4), 31-36.

Carbonell, J. G., Knoblock, C. A., \& Minton, S. (2014). Prodigy: An integrated architecture for planning and learning. In Architectures for intelligence ( $\mathrm{pp}$. 255-292). Psychology Press.

De Graaf, E., \& Kolmos, A. (2003). Characteristics of problem-based learning. International Journal of Engineering Education, 19(5), 657662.

Drake, S. M. (2007). Creating StandardsBased Integrated Curriculum: Aligning Curriculum, Content, Assessment, and Instruction. ERIC.

Ghosh, S., \& Pandya, H. V. (2008). Implementation of integrated learning program in neurosciences during first year of traditional medical course: Perception of students and faculty. BMC Medical Education, 8(1), 44.
Hardini, I., \& Puspitasari, D. (2012). Strategi pembelajaran terpadu. Yogyakarta: Familia.

Hasan, N. (2009). Islamizing formal education: Integrated Islamic school and a new trend in formal education institution in Indonesia.

Hasan, N. (2012). Education, young Islamists and integrated Islamic schools in Indonesia. Studia Islamika, 19(1).

Hashim, R. (2007). Intellectualism in higher Islamic traditional studies: Implications for the curriculum. American Journal of Islamic Social Sciences, 24(3), 92.

Hatton, K. (2012). Considering diversity, change and intervention: How the higher education curriculum looked in on itself. Widening Participation and Lifelong Learning, 13(1), 34-50.

Hill, A. (2007). Continuous curriculum assessment and improvement: A case study. New Directions for Teaching and Learning, 2007(112), 33-45.

Hopkins, D., \& Reynolds, D. (2001). The past, present and future of school improvement: Towards the third age. British Educational Research Journal, 27(4), 459-475.

Ingram, J. B. (2014). Curriculum integration and lifelong education: A contribution to the improvement of school curricula (Vol. 6). Elsevier.

Karseth, B. (2004). Curriculum changes and moral issues in nursing education. Nurse Education Today, 24(8), 638643.

Khuzaemah, E. (2016). Penerapan Model Terpadu dalam Pembelajaran Menulis Cerpen Islami. Indonesian Language Education and Literature, 1(2), 148161.

Koskinen, R. S. (2003). Method and system for creating an integrated learning 
environment with a pattern-generator and course-outlining tool for content authoring, an interactive learning tool, and related administrative tools.

Kurniawan, D. (2014). Pembelajaran terpadu tematik (Teori, praktik, dan penilaian). Bandung: Alfabeta.

Lubis, M. A. (2015). Effective implementation of the integrated Islamic education. Global Journal AlThaqafah, 5(1), 59-68.

Lubis, M. A., \& Wekke, I. S. (2009). Integrated Islamic education in Brunei Darussalam: The hopes and challenges. Educare, 1(2).

Lukens-Bull, R. A. (2001). Two sides of the same coin: Modernity and tradition in Islamic education in Indonesia. Anthropology \& Education Quarterly, 32(3), 350-372.

Moore, R. (2001). Policy-driven curriculum restructuring: Academic identities in transition? Higher Education Close up Conference, 2.

Moore, R. (2003). Curriculum restructuring in South African higher education: Academic identities and policy implementation. Studies in Higher Education, 28(3), 303-319.

Murfiah, U. (2017). Model pembelajaran terpadu di Sekolah Dasar. Jurnal Pesona Dasar, 1(1).

Osman, A. (2013). Integrating Islamic Value In Medical Teaching Curriculum: IIUM Experience. Bangladesh Journal of Medical Science, 12(2), 117-120.

Pahl-Wostl, C., \& Hare, M. (2004). Processes of social learning in integrated resources management. Journal of Community \& Applied Social Psychology, 14(3), 193-206.
Parsons, M. (2004). Art and integrated curriculum. In Handbook of research and policy in art education (pp. 783802). Routledge.

Pohl, F. (2009). Interreligious harmony and peacebuilding in Indonesian islamic education. In Peace psychology in Asia (pp. 147-160). Springer.

Salleh, M. J. (2009). The integrated islamic education: Principles and needs for thematic approaches. An Integrated Islamic Education: Need for Thematic Approaches, Singapore Islamic Education System (SIES) Seminar, Wisma MUIS, Singapore, On, 14.

Sylvén, L. K. (2004). Teaching in English or English teaching? On the effects of content and language integrated learning on Swedish learners' incidental vocabulary acquisition (PhD Thesis). Göteborg University.

Tam, M. (2014). Outcomes-based approach to quality assessment and curriculum improvement in higher education. Quality Assurance in Education, 22(2), 158-168.

Tan, C. (2012). Islamic education and indoctrination: The case in Indonesia. Routledge.

Van den Akker, J. (2004). Curriculum perspectives: An introduction. In Curriculum landscapes and trends (pp. 1-10). Springer.

Wati, U. A. (2010). Pengembangan Multimedia Pembelajaran untuk Mata Kuliah Pembelajaran Terpadu. Jurnal Penelitian Ilmu Pendidikan. Yogyakarta: FIP Universitas Negeri Yogyakarta.

Zuhdi, M. (2006). Modernization of Indonesian Islamic schools' curricula, 1945-2003. International Journal of Inclusive Education, 10(4-5), 415427. 